\title{
PENGARUH PENAMBAHAN EKSTRAK ABU JERAMI \\ DAN EKSTRAK KUNYIT TERHADAP ELASTISITAS DAN MUTU ORGANOLEPTIK MIE BASAH
}

\section{EFFECT OF ASH EXTRACTS AND TURMERIC EXTRACTS AGAINST ELASTICITY AND ORGANOLEPTIC QUALITY OF NOODLE}

\author{
Evo Tuska Serie ${ }^{1}$, Hesti Nur'aini ${ }^{2}$, Rahma Hidaiyanti ${ }^{3}$ \\ 1) Program Studi Teknologi Pertanian Fakultas Pertanian UNIVED \\ 2) Program Studi Teknologi Pertanian Fakultas Pertanian UNIVED \\ 3) Program Studi Teknologi Pertanian Fakultas Pertanian UNIVED
}

\begin{abstract}
ABSTRAK
Mie merupakan salah satu bentuk olahan pangan yang disukai oleh masyarakat. Tujuan penelitian ini adalah untuk mengetahui pengaruh penambahan ekstrak abu jerami padi dan ekstrak kunyit terhadap elastisitas dan mutu organoleptik mie basah. Penelitian ini menggunakan Rancangan Acak Lengkap (RAL) dengan variasi perlakuan kosentrasi penambahan ekstrak abu jerami $(3 \%, 5 \%$, dan $7 \%)$, dan penambahan ekstrak kunyit $(1 \%$, dan 1,5\%). Hasil analisis elastisitas mie basah menunjukkan bahwa seluruh perlakuan memberikan perbedaan yang nyata pada tingkat signifikansi 5\%. Adapun analisis organoleptik menunjukkan bahwa semua perlakuan memberikan pengaruh nyata terhadap warna, rasa, aroma, kekenyalan pada tingkat signifikansi 5\%, dimana ranking tertinggi terdapat pada perlakuan kosentrasi ekstrak abu jerami 5\% dan ekstrak kunyit 1\%.
\end{abstract}

Kata Kunci: mie basah, ekstrak abu jerami, ekstrak kunyit

\section{ABSTRACT}

Noodles is a food favored by the public. The purpose of this study was to determine the effect of rice straw ash extract and turmeric extract to the elasticity and organoleptic quality of wet noodle. This study used a completely randomized design with the addition of straw ash extract concentration treatment variations (3\%, 5\%, and $7 \%$ ), and the addition of turmeric extract ( $1 \%$, and $1.5 \%$ ). The results of the analysis indicate that the elasticity of wet noodles all treatments gave a real difference at a significance level of $5 \%$. The organoleptic analysis showed that all treatments gave significant effect on color, flavor, aroma, firmness at a significance level of $5 \%$, which is highest rank in the treatment of straw ash extract concentration of 5\% and $1 \%$ turmeric extract.

Keywords: wet noodles, straw ash extract, turmeric extract

\section{PENDAHULUAN}

Mie merupakan salah satu bentuk olahan pangan yang disukai oleh berbagai kalangan masyarakat karena penyajiaannya yang dapat dilakukan secara cepat, mudah dan dapat digunakakan sebagai alternatif untuk meningkatkan konsumsi kalori selain nasi (Gunawan, 2005). Salah satu jenis mie yang dikonsumsi oleh masyarakat adalah 
mie basah. Mie basah adalah jenis mie yang mengalami proses perebusan setelah tahap pemotongan. Kadar airnya dapat mencapai $52 \%$ sehingga daya simpannya relatif singkat (40 jam pada suhu kamar). Di Indonesia, mie basah dikenal dengan mie kuning atau mie bakso (Astawan, 2005).

Pada umumnya masalah yang sering dihadapai dalam pengembangan industri mie basah adalah produk tidak dapat disimpan dalam jangka waktu yang lama sehingga mutu organoleptiknya menurun. Kerusakan ini sangat merugikan karena dapat menurunkan mutu dan nilai gizi mie basah. Oleh karena itu, pada proses pembuatan mie basah diperlukan bahan tambahan untuk meningkatkan mutu organoleptiknya.

Ada beberapa macam persenyawaan organik yang dapat meningkatkan mutu organoletik produk pangan, yaitu bahan tambahan sintetik (hasil sintesa reaksi kimia) dan bahan tambahan alami (hasil ekstraksi bahan alami) (Ketaren, 1986). Penggunaan bahan tambahan makanan yang alami lebih aman dibandingkan yang sintetik. Menurut Hernani dan Rahardjo (2005), beberapa hasil penelitian yang dilakukan oleh para ilmuwan telah membuktikan bahwa bahan tambahan makanan sintetik mempunyai efek samping yang tidak diinginkan, yaitu berpotensi sebagai karsinogenik terhadap efek reproduksi dan metabolisme, bahkan dalam jangka waktu lama tidak terjamin keamanannya. Walapun bahan tambahan makanan sintetik seperti boraks dan formalin telah dilarang penggunaannya untuk produk pangan, akan tetapi produsen mie basah masih banyak menggunakannya. Beberapa penelitian yang dilakukan oleh Badan Pengawasan Obat dan Makanan (BPOM) di beberapa propinsi termasuk propinsi Bengkulu, secara kualitatif sample mie basah yang diteliti menunjukkan bahwa $72 \%$ mengandung boraks dan formalin (Anonim, 2006). Menurut beberapa produsen, keberadaan boraks dan formalin dalam mie basah, selain sebagai pengawet juga untuk menghasilkan tekstur yang lebih kenyal (Astawan, 2006). Berdasarkan permasalahan tersebut, maka diperlukan alternatif bahan tambahan makanan yang alami, aman digunakan dan dengan harga yang relatif murah.

Jerami merupakan hasil sampingan dari padi. Di Indonesia, jerami padi merupakan limbah pertanian yang tersedia melimpah dibandingkan dengan limbah pertanian lainnya (Shiddieqy, 2005). Produksi jerami padi tersedia 40 juta ton bahan kering/tahun. Meskipun produksi jerami cukup banyak tetapi pemanfaatannya masih terbatas sebagai bahan pangan ruminansia, alas kandang 
dan produksi kertas. Menurut Astawan (2002), abu jerami padi mengandung nilai ekonomis yang tinggi, karena air abu jerami padi juga dapat digunakan dalam pembuatan cincau hitam untuk memperoleh tekstur gel yang keras, tahan lama dan air abu jerami sangat efektif memperbaiki sifat fisik suatu bahan olahan pangan yang mengandung pati.

Nakatani (1992) dalam Trilaksani (2003) menyebutkan tanaman rempah mengandung antioksidan yang efektif, diantaranya adalah komponen aktif curcumin yang merupakan antioksidan berwarna kuning pekat yang diisolasi dari kunyit. Keefektifan antioksidan dari rempah-rempah ini kemudian menarik untuk dicobakan pada berbagai jenis makanan.

Selama ini belum ada yang memanfaatkan air abu jerami dan ekstrak kunyit sebagai bahan tambahan pada pembuatan mie basah untuk meningkatkan mutu organoletik mie basah. Oleh karena itu, pada penelitian ini akan dilakukan pembuatan mie basah dengan bahan tambahan air abu jerami dan ekstrak kunyit. Dengan demikian, akan diperoleh mie basah yang diterima oleh konsumen dari segi organoleptik. Tujuan penelitian ini adalah untuk mengetahui pengaruh penambahan air abu jerami padi dan ekstrak kunyit terhadap elastisitas dan sifat organoleptik mie basah yang dihasilkan.

\section{METODE PENELITIAN}

\section{Bahan dan Alat}

Bahan yang digunakan dalam penelitian ini adalah tepung terigu, air, garam, telur, ekstrak kunyit dan air abu jerami, sedangkan alat-alat yang digunakan dalam pengolahan mie basah yaitu pisau, sendok, tirisan, baskom, timbangan, wajan, cetakan mie (ampia) dan kompor.

\section{Pembuatan Air Abu Jerami}

Jerami padi sebanyak $1 \mathrm{~kg}$ dikeringkan dan dibakar sehingga menghasilkan abu jerami padi. Abu jerami padi yang dihasilkan dari proses pembakaran jerami padi yang telah dikeringkan, direndam dalam air selama 24 jam sesuai dengan perlakuan, yaitu untuk konsentrasi $3 \%$ (3 gr abu jerami padi dalam 97 gram air), 5 $\%$ (5 gr abu jerami dalam 95 gram air), dan $7 \%$ (7 gram abu jerami dalam $93 \%$ gram air). Air rendaman tersebut disaring sehingga diperoleh ekstrak abu jerami yang jernih dan tidak berwarna.

\section{Pembuatan Ekstrak Kunyit}

Kunyit sebanyak 100 gram dikupas, dicuci hingga bersih, dan diparut. Hasil parutan diperas dan disaring sehingga diperoleh ekstrak kunyit tanpa ampas. Pada penelitian ini dilakukan penambahan ekstrak kunyit sebanyak 1 
$\%$ dan $1,5 \%$ dari berat tepung terigu yang digunakan, yaitu 1 gram dan 1,5 gram.

\section{Pembuatan Mie Basah}

Sebanyak 100 gram tepung terigu, 0,5 gram garam, ekstrak kunyit dan 30 gram ekstrak abu jerami sesuai perlakuan dicampurkan dalam baskom plastik. Campuran tersebut diaduk hingga merata sehingga menjadi adonan yang homogen. Adonan ditekan di antara dua roller (gigi 1) untuk mendapatkan lempeng adonan setebal $1 \mathrm{~cm}$. Pelempengan dilakukan kembali di antara dua roller (gigi 3) 7 10 kali untuk memperoleh lepengan yang lebih tipis dengan ketebalan $1-2 \mathrm{~mm}$. Lempengan adonan dicetak dengan roller khusus pencetakan mie pada ampia sehingga menghasilkan benang-benang mie berdiameter $0,175-0,321 \mathrm{~cm}$. Benang-benang mie tersebut direbus dalam air mendidih selama 2 menit sambil diaduk perlahan. Mie hasil perebusan ditiriskan dalam wadah plastik, selanjutnya didinginkan dan ditambahkan minyak sayur agar kelihatan halus dan tidak lengket.

Rancangan penelitian yang digunakan adalah rancangan acak lengkap (RAL) dengan menggunakan dua faktor beda, yaitu : Penambahan ekstrak abu jerami (J) : $3 \%$ (3 gr abu jerami padi dalam 97 gram air), $5 \%$ (5 gr abu jerami dalam 95 gram air), dan $7 \%$ (7 gram abu jerami dalam $93 \%$ gram air). Penambahan ekstrak kunyit $(\mathrm{K}): 1 \%$ dan $1,5 \%$ dari tepung terigu yang digunakan.

\section{HASIL DAN PEMBAHASAN}

\section{Elastisitas Mie Basah}

Dalam penelitian ini kekenyalan mie basah diketahui melalui akumulasi waktu yang dibutuhkan oleh mie untuk menahan beban 9,86 gram yang diberikan sampai mie tersebut putus. Semakin lama waktu yang dibutuhkan mie untuk menahan beban sampai mie tersebut putus, maka semakin elastis mie yang dihasilkan.

Hasil analisis keragaman terhadap waktu putus mie basah yang terdapat pada lampiran 3, menunjukan perbedaan nyata antara perlakuan pada tingkat signifikansi 5\%, karena nilai $\mathrm{F}$ hitung lebih besar dari nilai $\mathrm{F}$ tabel. Hal ini menunjukkan bahwa penambahan ekstrak abu jerami dan ekstrak kunyit pada mie basah dengan berbagai tingkat konsentrasi berpengaruh terhadap elastisitas mie basah yang dihasilkan. Untuk melihat nilai rata- rata waktu putus mie berdasarkan penambahan beban tertentu pada berbagai perlakuan dapat dilihat pada Tabel 1. Hasil analisis statitik pada Tabel 1 menunjukkan bahwa nilai rata- rata ranking tertinggi dicapai oleh perlakuan 5\% ekstrak abu jerami dan 1\% ekstrak kunyit dimana waktu 
putus mie 85,67 detik, yang berbeda nyata dengan seluruh perlakuan.

Tabel 1. Pengaruh Penambahan Ekstrak Abu Jerami dan Ekstrak Kunyit terhadap Rata-rata Waktu Putus Mie Basah (detik)

\begin{tabular}{cccc}
\hline $\begin{array}{c}\text { Konsentrasi } \\
\text { ekstrak abu } \\
\text { jerami (\%) }\end{array}$ & \multicolumn{3}{c}{ Konsentrasi ekstrak kunyit (\%) } \\
\cline { 2 - 4 } 0 & $63.33^{\mathrm{g}}$ & 1.5 & \\
\hline 3 & - & $74.33^{\mathrm{e}}$ & $71.33^{\mathrm{f}}$ \\
5 & - & $85.67^{\mathrm{a}}$ & $82.33^{\mathrm{b}}$ \\
7 & - & $79.33^{\mathrm{c}}$ & $76.67^{\mathrm{d}}$ \\
\hline
\end{tabular}

Ket : Nilai rata-rata yang diikuti oleh kode huruf yang berbeda menunjukkan adanya perbedaan yang nyata pada tingkat signifikansi $5 \%$

Ekstrak akali dapat meningkatkan $\mathrm{pH}$ adonan sehingga sebagian besar sistem enzim yang terdapat didalam tepung terigu tidak berfungsi, terutama enzim protease (enzim yang memecah protein menjadi asam-asam amino). Menurut Sumantha et al. (2005), enzim protease stabil pada kisaran $\mathrm{pH} 7,0-7,5$. Pemberian ekstrak abu jerami dapat menghambat aktifitas enzim protease. Aktifitas enzim protease perlu dihambat agar protein tidak terurai karena penguraian protein dapat menyebabkan mie menjadi tidak kenyal.

\section{Sifat Organoleptik Mie Basah}

Hasil analisis keragaman terhadap variabel organoleptik menunjukkan bahwa perlakuan memberikan pengaruh yang nyata terhadap warna, aroma, rasa, dan kekenyalan pada tingkat signifikansi 5\%. Pengaruh yang nyata ini dilihat dari nilai $\mathrm{F}$ hitung yang lebih besar dari $\mathrm{F}$ tabel.

\section{Warna Mie Basah}

Hasil analisis uji warna mie dengan penambahan ekstrak abu jerami dan ekstrak kunyit yang menggunakan analisis sidik ragam, menunjukkan perbedaan yang nyata antar perlakuan pada tingkat signifikansi $5 \%$, karena nilai $\mathrm{F}$ hitung lebih besar dari nilai $\mathrm{F}$ tabel. Nilai rata-rata ranking tertinggi dapat dicapai oleh kosentrasi ekstrak abu jerami $5 \%$ dan ekstrak kunyit $1 \%$, yaitu 4,32 (sangat suka) yang berbeda nyata dengan seluruh perlakuan. Kosentrasi ekstrak abu jerami 7\% dan ekstrak kunyit $1 \%$ memiliki nilai rata- rata ranking sebesar 3,81 (suka) yang berbeda nyata dengan seluruh perlakuan. 
Tabel 2. Rekapitulasi Rata-rata Hasil Uji Organoleptik Mie Basah dengan Penambahan Ekstrak Abu Jerami dan Ekstrak Kunyit

\begin{tabular}{cccccc}
\hline \multicolumn{2}{c}{ Konsentrasi (\%) } & \multicolumn{4}{c}{ Variabel organoleptik } \\
\hline $\begin{array}{c}\text { Ekstrak abu } \\
\text { jerami }\end{array}$ & $\begin{array}{c}\text { Ekstrak } \\
\text { kunyit }\end{array}$ & Warna & Rasa & Aroma & Kekenyalan \\
\hline 0 & 0 & 2.17 & 2,27 & 2,39 & 2,39 \\
3 & 1 & 3,42 & 3,51 & 3,53 & 3,49 \\
3 & 1.5 & 3,11 & 3,16 & 3,05 & 3.34 \\
5 & 1 & 4,32 & 4,20 & 4,15 & 4,28 \\
5 & 1.5 & 3,34 & 3,44 & 3,42 & 4,00 \\
7 & 1 & 3,81 & 3,88 & 3,83 & 3,91 \\
7 & 1.5 & 3,19 & 3,26 & 3,26 & 3,67 \\
\hline
\end{tabular}

Ket : Skala penilaian : 1 (sangat tidak suka), 2 (tidak suka), 3 (agak suka), 4 (suka), 5 (sangat suka).

Tabel 3. Pengaruh Penambahan Ekstrak Abu Jerami dan Ekstrak Kunyit terhadap Warna Mie Basah secara Organoleptik

\begin{tabular}{cccc}
\hline $\begin{array}{c}\text { Konsentrasi } \\
\text { ekstrak abu }\end{array}$ & \multicolumn{3}{c}{ Konsentrasi ekstrak kunyit (\%) } \\
$\begin{array}{c}\text { jerami (\%) } \\
0\end{array}$ & 0 & 1 & 1.5 \\
\hline 3 & $2.17^{\mathrm{e}}$ & - & - \\
5 & - & $3.42^{\mathrm{c}}$ & $3.11^{\mathrm{d}}$ \\
7 & - & $4.32^{\mathrm{a}}$ & $3.34^{\mathrm{cd}}$ \\
\hline
\end{tabular}

Ket : - Nilai rata-rata yang diikuti oleh kode huruf yang berbeda menunjukkan adanya perbedaan yang nyata pada tingkat signifikansi $5 \%$

- Skala penilaian : 1 (sangat tidak suka), 2 (tidak suka), 3 (agak suka), 4 (suka), 5 (sangat suka)

Kosentrasi ekstrak abu jerami 3\% dan ekstrak kunyit $1 \%$ yang memiliki nilai rata-rata skor penilaian sebesar 3,42 (suka) berbeda tidak nyata dengan kosentrasi ekstrak abu jerami 5\% dan ekstrak kunyit 1,5\% sebesar 3,34 (biasa), sedangkan kosentrasi ekstrak abu jerami $5 \%$ dan ekstrak kunyit 1,5\% juga berbeda tidak nyata dengan kosentrasi air ekstrak jerami $7 \%$ dan ekstrak kunyit $1,5 \%$ sebesar 3,19 (biasa) dan kosentrasi ekstrak abu jerami 3\% dan ekstrak kunyit
$1,5 \%$ sebesar 3,11 (biasa) tetapi berbeda nyata dengan perlakuan tanpa ekstrak abu jerami dan ekstrak kunyit yang memiliki nilai rata-rata terendah sebesar 2,17 ( tidak suka)

Winarno (2002) menyatakan bahwa uji warna lebih banyak melihat indera penglihatan dan merupakan salah satu indikator untuk menentukan apakah suatu bahan pangan diterima atau tidak oleh masyarakat konsumen, karena makanan yang berkualitas (rasanya enak, bergizi 
dan bertekstur baik) belum tentu akan disukai oleh konsumen bilamana bahan makanan tersebut memiliki warna yang tidak sedap dipandang atau menyimpang dari warna aslinya.

Timbulnya warna kekuningan ini disebabkan oleh sifat ekstrak abu jerami yang bersifat alkalis dan juga ditambahkan adanya ekstrak kunyit. Menurut Sunaryo dan Wibowo (2005), warna adonan mie menjadi kekuningan akibat terjadi reaksi antara alkali dan pigmen flavonoid yang berasal dari tepung terigu. Dengan demikian, berarti mie basah yang dihasilkan oleh kosentrasi ekstrak abu jerami $5 \%$ dan ekstrak kunyit $1 \%$ berpeluang paling diterima oleh masyarakat konsumen.

\section{Rasa Mie Basah}

Hasil analisis sidik ragam untuk uji warna, menunjukkan perbedaan yang nyata antar perlakuan pada tingkat signifikansi 5\%, karena nilai $\mathrm{F}$ hitung lebih besar dari nilai $\mathrm{F}$ tabel. Hasil uji DMRT yang diperoleh ditampilkan pada Tabel 4.

Tabel 4. Pengaruh Penambahan Ekstrak Abu Jerami dan Ekstrak Kunyit terhadap Rasa Mie Basah secara Organoleptik

\begin{tabular}{cccc}
\hline $\begin{array}{c}\text { Konsentrasi } \\
\text { ekstrak abu }\end{array}$ & \multicolumn{3}{c}{ Konsentrasi ekstrak kunyit (\%) } \\
\cline { 2 - 4 } jerami (\%) & 0 & 1 & 1.5 \\
\hline 0 & $2.27^{\mathrm{e}}$ & - & - \\
3 & - & $3.51^{\mathrm{c}}$ & $3.16^{\mathrm{d}}$ \\
5 & - & $4.20^{\mathrm{a}}$ & $3.44^{\mathrm{cd}}$ \\
7 & - & $3.88^{\mathrm{b}}$ & $3.26^{\mathrm{d}}$ \\
\hline
\end{tabular}

Ket : - Nilai rata-rata yang diikuti oleh kode huruf yang berbeda menunjukkan adanya perbedaan yang nyata pada tingkat signifikansi $5 \%$

- Skala penilaian : 1 (sangat tidak suka), 2 (tidak suka), 3 (agak suka), 4 (suka), 5 (sangat suka)

Nilai rata-rata ranking tertinggi dicapai oleh kosentrasi ekstrak abu jerami 5\% dan ekstrak kunyit 1\% yaitu 4,20 (sangat suka) yang berbeda nyata dengan seluruh perlakuan. Konsentrasi ekstrak abu jerami 7\% dan ekstrak kunyit 1\% sebesar 3,88 (suka) berbeda nyata juga dengan seluruh perlakuan. Kosentrasi ekstrak abu jerami $3 \%$ dan ekstrak kunyit $1 \%$ sebesar 3,51 (biasa) berbeda tidak nyata dengan kosentrasi ekstrak abu jerami 5\% dan ekstrak kunyit $1,5 \%$ sebesar 3,44 (biasa), sedangkan kosentrasi ekstrak abu jerami 5\% dan ekstrak kunyit 1,5\% berbeda tidak nyata dengan kosentrasi ekstrak abu jerami 7\% dan ekstrak kunyit 1,5\% sebesar 3,26 (biasa) dan kosentrasi ekstrak abu jerami 3\% dan ekstrak kunyit 
1,5\% sebesar 3,16 (biasa), tetapi berbeda nyata dengan perlakuan tanpa ekstrak abu jerami dan ekstrak kunyit yang memiliki nilai rata-rata terendah sebesar 2,27 (biasa).

Menurut Soekarto (1985), bahwa uji rasa banyak melibatkan indera lidah yang dapat diketahui kelarutan bahan makanan tersebut dalam saliva dan kontak dengan syaraf perasa. Peramuan rasa merupakan suatu sugesti kejiwaan seseorang terhadap makanan serta menentukan nilai kepuasan orang memakannya. Jadi, dengan demikian hasil tersebut semakin memperkuat peluang bahwa mie dengan penambahan ekstrak abu jerami dan ekstrak kunyit yang dihasilkan oleh konsentrasi ekstrak abu jerami 5\% dan ekstrak kunyit $1 \%$ paling dapat diterima oleh masyarakat konsumen.

\section{Aroma Mie Basah}

Hasil analisis sidik ragam untuk uji aroma yang terdapat pada lampiran 6, menunjukkan perbedaan yang nyata antar perlakuan pada tingkat signifikansi 5\%, karena nilai $\mathrm{F}$ hitung lebih besar dari nilai F tabel. Hasil uji DMRT yang diperoleh ditampilkan pada tabel 5.

\section{Tabel 5. Pengaruh Penambahan Ekstrak Abu Jerami dan Ekstrak Kunyit terhadap Aroma Mie Basah secara Organoleptik.}

\begin{tabular}{cccc}
\hline Konsentrasi air & \multicolumn{3}{c}{ Konsentrasi ekstrak kunyit $(\%)$} \\
\cline { 2 - 4 } abu jerami $(\%)$ & 0 & 1 & 1.5 \\
\hline 0 & $2.39^{\mathrm{e}}$ & - & - \\
3 & - & $3.53^{\mathrm{c}}$ & $3.05^{\mathrm{d}}$ \\
5 & - & $4.15^{\mathrm{a}}$ & $3.42^{\mathrm{cd}}$ \\
7 & - & $3.83^{\mathrm{b}}$ & $3.26^{\mathrm{d}}$ \\
\hline
\end{tabular}

Ket : - Nilai rata-rata yang diikuti oleh kode huruf yang berbeda menunjukkan adanya perbedaan yang nyata pada tingkat signifikansi $5 \%$

- Skala penilaian : 1 (sangat tidak suka), 2 (tidak suka), 3 (agak suka), 4 (suka), 5 (sangat suka)

Nilai rata-rata ranking tertinggi dicapai oleh kosentrasi ekstrak abu jerami 5\% dan ekstrak kunyit 1\% yaitu 4,15 (sangat suka) yang berbeda nyata dengan seluruh perlakuan. Kosentrasi ekstrak abu jerami 7\% dan ekstrak kunyit 1\% memiliki nilai rata-rata sebesar 3,81 (suka). Kosentrasi ekstrak abu jerami 3\% dan ekstrak kunyit
1\% sebesar 3,53 (biasa) berbeda tidak nyata dengan kosentrasi ekstrak abu jerami 5\% dan ekstrak kunyit 1,5\% sebesar 3,42 (biasa). Kosentrasi ekstrak abu jerami 5\% dan ekstrak kunyit 1,5\% berbeda tidak nyata dengan kosentrasi ekstrak abu jerami 7\% dan ekstrak kunyit 1,5\% sebesar 3,26 (agak suka) dan 
kosentrasi ekstrak abu jerami 3\% dan ekstrak kunyit 1,5\% sebesar 3,05 (agak suka). Sedangkan nilai rata-rata terendah terdapat pada perlakuan tanpa ekstrak abu jerami dan ekstrak kunyit sebesar 2,39 (tidak suka) yang berbeda nyata dengan perlakuan lainnya. Hal ini berarti sebagian besar mie basah dengan penambahan ekstrak abu jerami dan ekstrak kunyit dari segi aroma berbeda dengan mie tanpa penambahan ekstrak abu jerami dan ekstrak kunyit ( kontrol).

Menurut Winarno (2002), bahwa uji aroma lebih banyak menggunakan indera penciuman, karena kelezatan suatu makanan sangat ditentukan oleh aroma makanan tersebut dan dapat merupakan salah satu indikator penting dalam menentukan kualitas bahan pangan.
Umumnya konsumen akan menyukai bahan pangan jika mempunyai aroma khas yang tidak menyimpang dari aroma normal.

\section{Kekenyalan Mie Basah}

Hasil analisis sidik ragam untuk uji kekenyalan mie basah dengan penambahan ekstrak abu jerami dan ekstrak kunyit yang terdapat pada lampiran 7, menunjukkan perbedaan yang nyata antar perlakuan pada tingkat signifikansi 5\%, karena $\mathrm{F}$ hitung lebih besar dari F tabel. Hasil uji DMRT dapat dilihat pada Tabel 6. Nilai rata-rata ranking tertinggi dicapai oleh kosentrasi ekstrak abu jerami 5\% dan ekstrak kunyit $1 \%$ sebesar 4,28 (sangat suka) yang berbeda nyata dengan seluruh perlakuan.

Tabel 6. Pengaruh Penambahan Ekstrak Abu Jerami dan ekstrak kunyit terhadap kekenyalan mie basah secara organoleptik

\begin{tabular}{cccc}
\hline Konsentrasi air & \multicolumn{3}{c}{ Konsentrasi ekstrak kunyit (\%) } \\
\cline { 2 - 4 } abu jerami (\%) & 0 & 1 & 1.5 \\
\hline 0 & $2.39^{\mathrm{e}}$ & - & - \\
3 & - & $3.49^{\mathrm{c}}$ & $3.34^{\mathrm{d}}$ \\
5 & - & $4.28^{\mathrm{a}}$ & $4.00^{\mathrm{b}}$ \\
7 & - & $3.91^{\mathrm{b}}$ & $3.67^{\mathrm{c}}$ \\
\hline
\end{tabular}

Ket : - Nilai rata-rata yang diikuti oleh kode huruf yang berbeda menunjukkan adanya perbedaan yang nyata pada tingkat signifikansi 5\%

- Skala penilaian : 1 (sangat tidak suka), 2 (tidak suka), 3 (agak suka), 4 (suka), 5 (sangat suka)

Kosentrasi ekstrak abu jerami 5\% dan ekstrak kunyit $1,5 \%$ sebesar 4,00 (suka) berbeda tidak nyata dengan kosentrasi ekstrak abu jerami 7\% dan ekstrak kunyit
$1 \%$ sebesar 3,91 (suka). Kosentrasi ekstrak abu jerami 7\% dan ekstrak kunyit 1,5\% sebesar 3,67 (biasa) berbeda tidak nyata dengan kosentrasi ekstrak abu 
jerami 3\% dan ekstrak kunyit 1\% sebesar 3,49 (biasa), sedangkan kosentrasi ekstrak abu jerami 3\% dan ekstrak kunyit $1 \%$ berbeda tidak nyata dengan kosentrasi ekstrak abu jerami 3\% dan ekstrak kunyit 1,5\% sebesar 3,34 (biasa), tetapi berbeda nyata dengan perlakuan tanpa ekstrak abu jerami dan ekstrak kunyit yang memiliki nilai rata-rata terendah yaitu sebesar 2,39 (tidak suka). Dengan demikian, berarti mie basah yang dihasilkan oleh kosentrasi ekstrak abu jerami $5 \%$ dan ekstrak kunyit 1\% berpeluang paling diterima oleh konsumen.

\section{SIMPULAN}

Elastisitas mie basah dengan perlakuan penambahan ekstrak abu jerami $5 \%$ dan ekstrak kunyit $1 \%$ lebih tinggi dibandingkan dengan perlakuan lainnya. Hasil uji organoleptik memperlihatkan bahwa penambahan ekstrak abu jerami dan ekstrak kunyit mie basah dengan perlakuan penambahan ekstrak abu jerami $5 \%$ dan ekstrak kunyit $1 \%$ lebih disukai oleh panelis dibandingkan dengan perlakuan lainnya.

\section{DAFTAR PUSTAKA}

Anonim. 2006. Kunyit dan Air Abu jerami Bisa Menjadi Alternatif Formalin. http;// www.mediaindo.co.id/berita.asp?i $\mathrm{d}=86717$ (1 Juni 2012).
Astawan, M. 2002. Cincau Hitam, Pelepas Dahaga. http://www.sedap-

sekejap.com/ artikel/2002/edisi4/files/tekno.ht m. (1 Juni 2012).

Astawan, M. 2005. Membuat Mie dan Bihun. Cet 7. Penebar Swadaya Jakarta.

Astawan , M. 2006. Mi, Lezat Bergizi Tetapi Rawan Formalin. http://www.depkes.go.id/indeks.p $\mathrm{hp}$ ?option $=$ articles\&task $=$ viewaar ticle \&artid $=275 \&$ Itemid $=3$

Gunawan, B. 2005. Studi Tentang Manfaat Rumput Laut (Euchema cottonii) dalam Meningkatkan Nilai Kandungan serat dan Yodium Pada Mie Basah. Neptunus V12 (1); $59-66$.

Hernani dan Mojo Rahardjo. 2005. Tanaman Berkhasiat Antioksidan. Penebar Swadaya. Depok

Shiddieqy, IM. 2005. Pakan Ternak Jerami Olahan. http://www.pikiranrakyat.com/cet ak/2005/0305/24/cakrawala/lainn ya1. htm. (3 Juni 2012).

Soekarta, S.T. 1985. Penilaian Organoleptik Untuk Industri Pangan dan Hasil Pertanian. Bhatara Karya Aksara. Jakarta

Sumantha, A., C. Sandhya, G. Szakacs, C.R. Soccol, A. Pandey. 2005. Production and Partial Purification of a Neutral Mellaprotease by Fungal Mixed Substrat Fermentation. http://public.caret.hr/ftbrfd/43313.pdf. (4 Juni 2012).

Sunaryo, E.S,. A. Wibowo. 2005. Mengenal Lebih Jauh Mie Instan. Pelangi Cendikia. Jakarta

Trilaksani, W. 2003. Antioksidan: Jenis, Sumber, Mekanisme Kerja dan Peran terhadap Kesehatan. http://rudyct.tripod.com/sem2_02 3/wini_trilaksani.htm. (4 Juni 2012). 
Winarno, F.G., 2002. Kimia Pangan Gizi.

Jakarta.

Gramedia Pustaka Utama. 